\title{
Journey through the Defenses of the Festung Saint-Malo (FR)-1
}

\author{
Giancarlo T. Tomezzoli*, Louis L. Pottier \\ Etno-Archaeological Observatory, Munich, Germany \\ Email: *gt21949@gmx.de
}

How to cite this paper: Tomezzoli, G. T., \& Pottier, L. L. (2016). Journey through the Defenses of the Festung Saint-Malo (FR)-1.

Archaeological Discovery, 4, 125-142. http://dx.doi.org/10.4236/ad.2016.44010

Received: July 27, 2016

Accepted: September 6, 2016

Published: September 9, 2016

Copyright $\odot 2016$ by authors and Scientific Research Publishing Inc. This work is licensed under the Creative Commons Attribution International License (CC BY 4.0).

http://creativecommons.org/licenses/by/4.0/

(c) (i) Open Access

\begin{abstract}
The Festung (Fortress) Saint-Malo was defended by about 500 German military structures constructed, in the period December 1941-June 1944, under the direction of the Organisation Todt. They diversify from simple tobrucks (Vf 58, Vf 61) up to the great bunkers of the Cité d'Alet. This article is a survey presenting some of them on the East side of the Festung, deemed of interest. Many of them remain visible and accessible and witness the confidence of the Germans in static military offensive and defensive structures. The Kullak artillery battery, the Pointe de la Varde support point, the Bastion de Saint Ideuc base, the Hôpital des Rosais base have lost their military value and because of their obsolescence with respect to the modern military doctrines based on a rapid first strike and precision bombing, they will never recover a military one. Their bunkers remain silent witnesses of a recent tragic period in the life of Saint-Malo. On the contrary, the bunkers of the Les Ormeaux artillery battery and the cisterns of the Ville Besnard logistic base are well integrated in the urban context and support the actual exigencies of Saint-Malo.
\end{abstract}

\section{Keywords}

Saint-Malo, Festung, France, Atlantic Wall, World War II, Military, German

\section{Introduction}

The Festung (Fortress) Saint-Malo was defended by about 500 military structures constructed, in the period December 1941-June 1944, under the direction of the Organisation Todt (Corlouer, 1965). They diversify from simple tobrucks (Vf 58, Vf 61) up to the great bunkers of the Cité d'Alet. This article is a survey not intended for presenting exhaustively all these structures, but for presenting some of them on the East side of the Festung, deemed of interest. In particular, the visits permitted to find many bunkers and so, indirectly, to feel the confidence that the defenders of the Fes- 
tung had in them (Figure 1).

\section{The Kullak Artillery Battery}

The Kullak artillery battery (AOK 7, KVA A1, KvGr Rance, KvUGr Cancale, RA 110) (Dupont, 1994) (48³9'59.9"N, $\left.1^{\circ} 55^{\prime} 31.0^{\prime \prime} \mathrm{W}\right)$ (Figure 2 \& Figure 3) was not far from the city of Saint Coulomb. Located between the castle of La Mettrie aux Louëts and the Pont-Gilles farm, practically on the shores of the pond of Sainte Suzanne, it was the first important battery of the Festung at the East of Saint-Malo. Near the end of the war, the castle hosted the headquarter of the 602. Osttruppen Bataillon and of the battery. It included four bunkers R669, an enlarged version of the bunker R612, each hosting a captured French K331 105 mm gun. Theoretically, such a battery had to be completed with other bunkers: a fire direction bunker, personnel shelters, ammunition bunkers, storage bunkers and others, but here only the four R669 are up today present. This

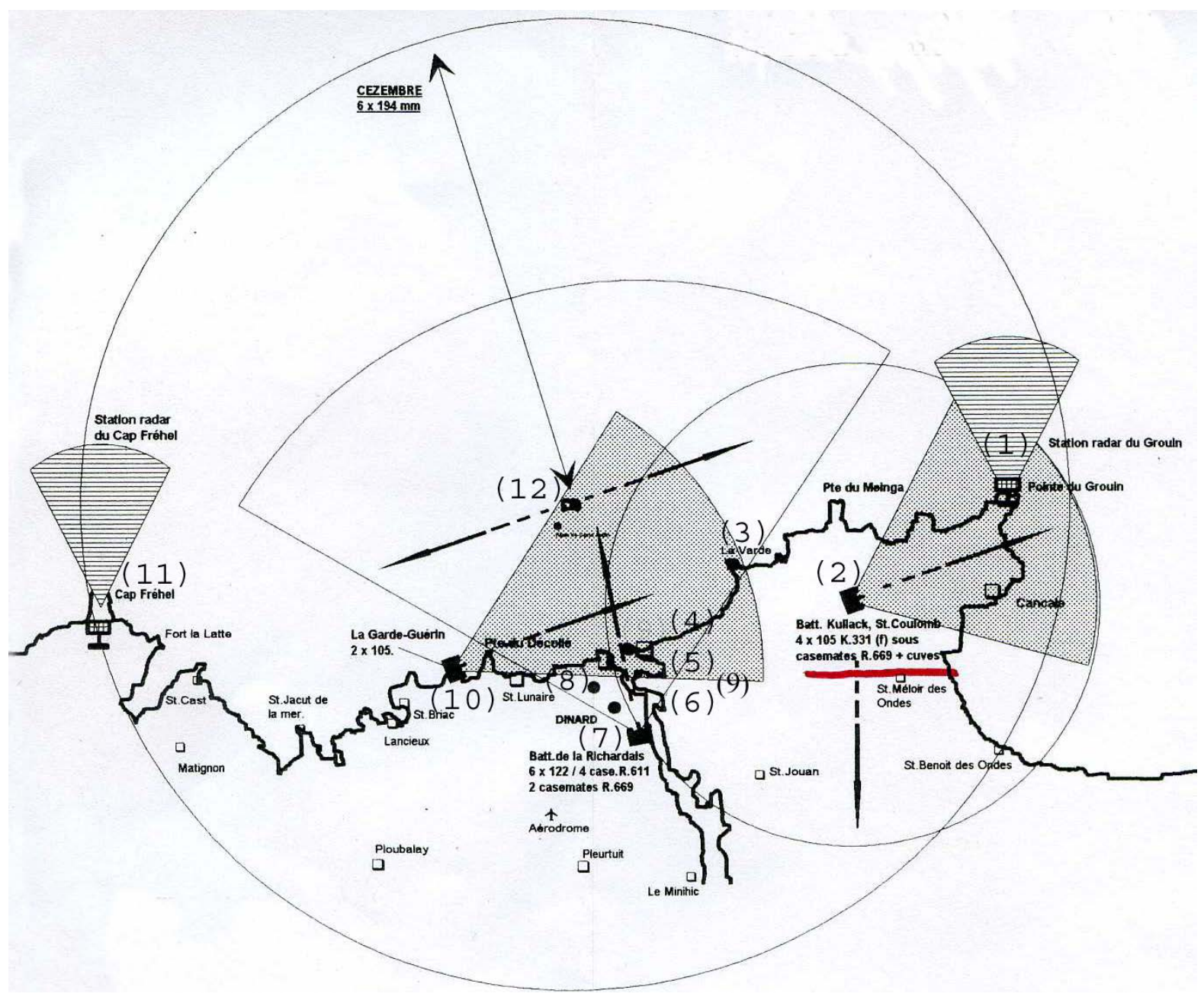

Figure 1. Festung Saint-Malo (Corlouer, 1965): (1) Grouin radar station, (2) Kullak artillery battery, (3) Pointe de la Varde support point, (4) Ville Besnard logistic base, (5) Bastion of Saint Ideuc base, (6) Les Ormeaux artillery battery (II 405, S 160a), (7) Ville Es Meniers artillery battery, (8) Talasso artillery battery: Dinard, (9) Hôpital du Rosais bunker, (10) Garde Guerin radar station/base, (11) Cap Fréhel radar station, (12) Cezambre island. 


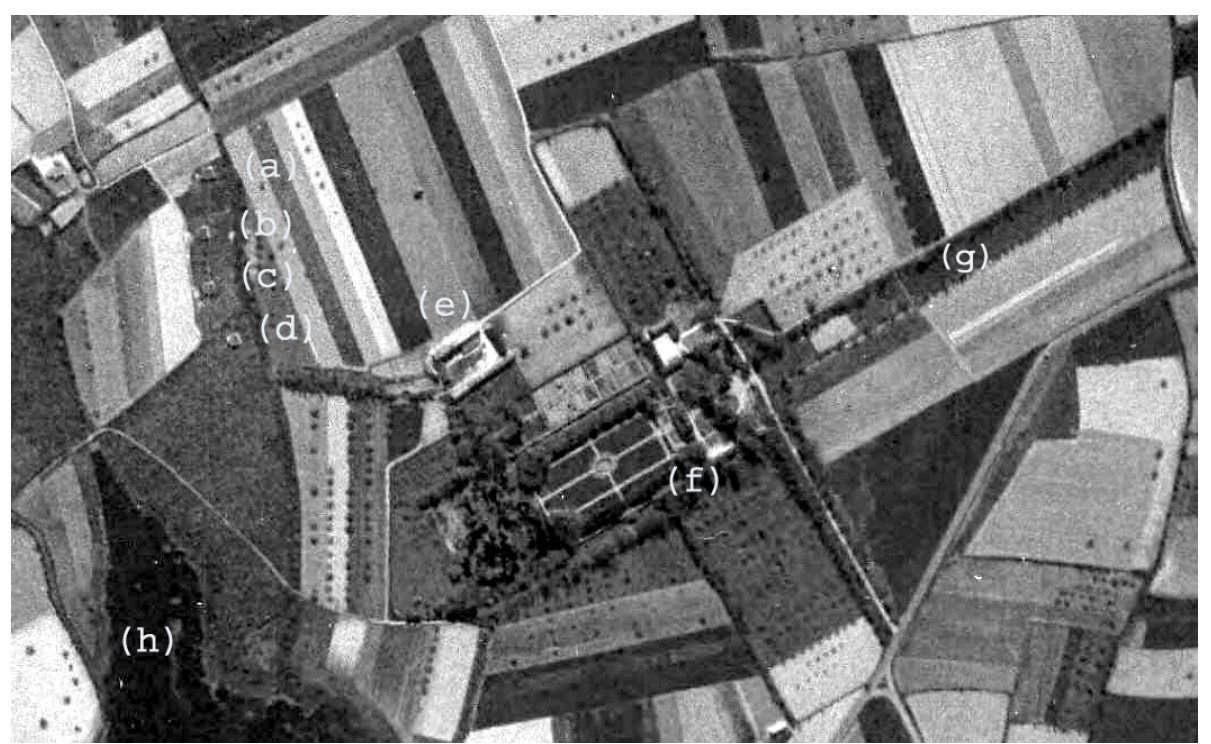

Figure 2. Kullak battery on 1948: (a)-(d) bunkers R669, (e) Pont-Gilles farm (48 $40^{\prime} 3.88^{\prime \prime N}$, $1^{\circ} 55^{\prime} 42.45^{\prime \prime} \mathrm{W}$, (f) Mettrie aux Louëts castle $\left(48^{\circ} 40^{\prime} 6.5^{\prime \prime} \mathrm{N}, 1^{\circ} 55^{\prime} 50.8^{\prime \prime} \mathrm{W}\right)$, (g) access avenue of the castle, (h) Sainte Suzanne ponds

IGNF_PVA_1948-04-16_C3639-0511_1948_MISSIONBRETAGNE10_0095.

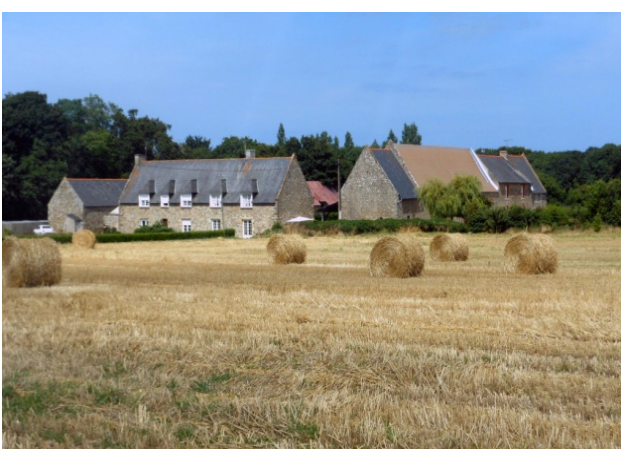

(a)

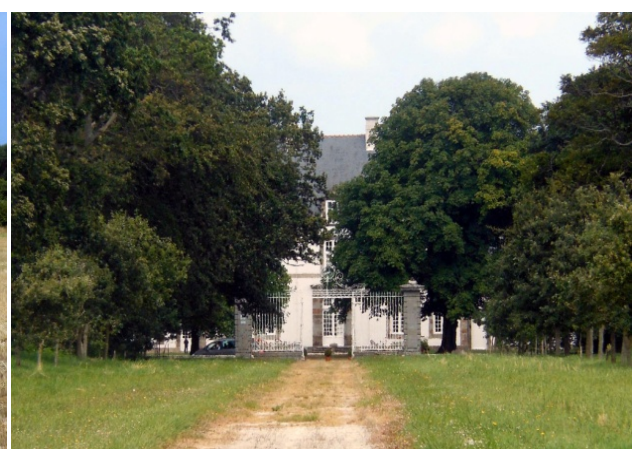

(b)

Figure 3. (a) Pont-Gilles farm, lodgement of the military personnel of the Kullak battery, view from the battery; (b) Mettrie aux Louëts castle headquarter of the 602. Osttruppen Bataillon and of the Kullak battery, view from the access avenue.

could means that they were the only bunkers of the battery terminated at the moment of the battle of Saint-Malo. The personnel, ammunitions and materials were hosted in the nearby castle, farm and/or in disappeared barracks in the surroundings. The battery was streng- thened by some anti-aircraft guns and by a unit of paratroopers for its close defense. During the battle of Saint-Malo, the battery sustained the defences of the sea shore around the city of Cancale. In revenge of an intense bombardment on 5-6th $\mathrm{Au}$ gust, 1944, the personnel of the 602. Osttruppen Bataillon did not hesitate to fire on the city killing thirty-six people and injuring about sixty.

The visit of the Kullak battery, under the guidance of Mr. Buret, inhabitant of the Pont Gilles farm, took place on the afternoon of 31st July 2012. It permitted to identify in a mature corn field, three of the four bunkers R669 (Figures 2(a)-(c)) of the battery. 
The fourth bunker (Figure 2(d)), engulfed in a thick wood was not reached. The three bunkers (a)-(c) presented well preserved concrete structures without visible damages due to said bombardment and/or combats although all the original internal furniture disappeared (Figures 4-14). Mr. Buret confirmed that during the WWII German soldiers were lodged at the farm and at the castle.

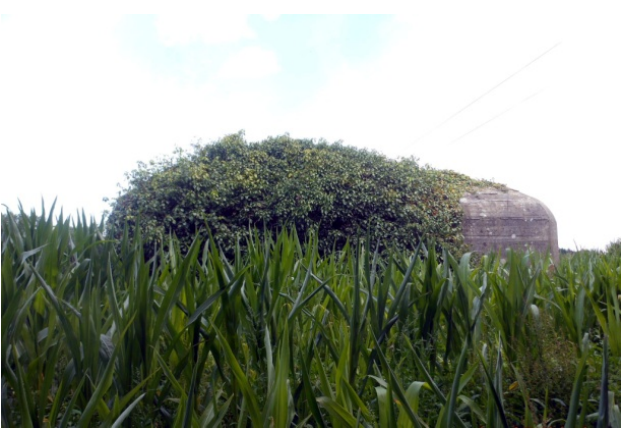

(a)

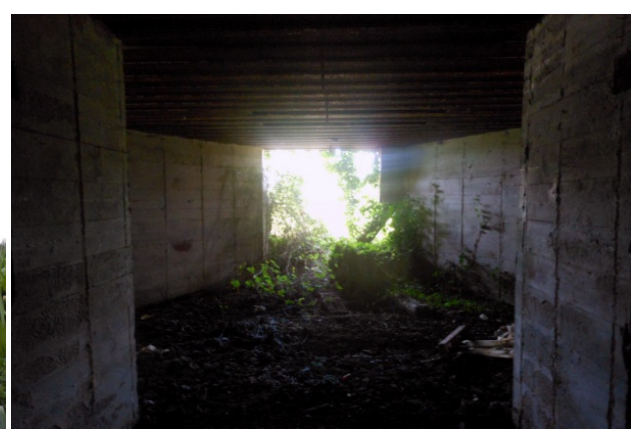

(b)

Figure 4. Kullak battery: (a) R669 (a) — rear side covered by vegetation; (b) R669 (a) —front side aperture of the fire room.

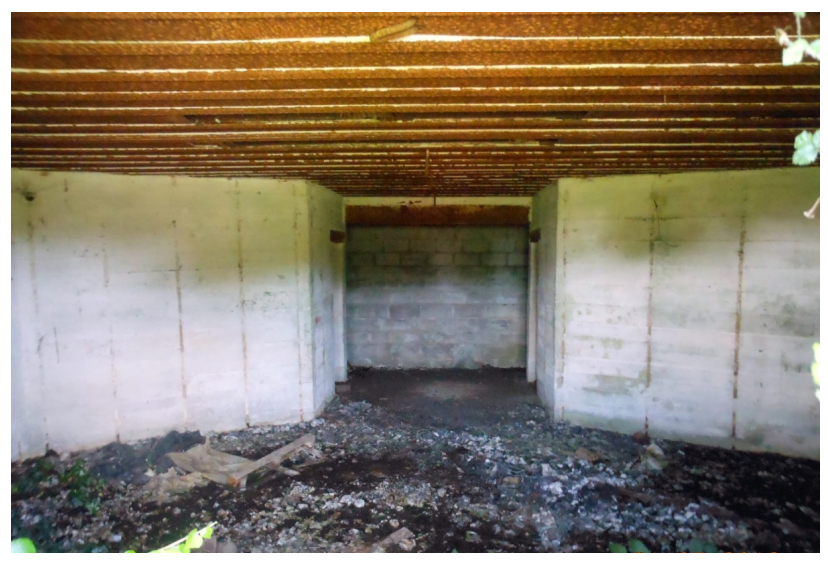

Figure 5. Kullak battery: R669 (a) fire room-at the centre walled rear side aperture, on the left entrance of the ammunition room, on the right entrance of the combat gas extraction system room, on the metal ceiling distorted joint for the gun lifting.

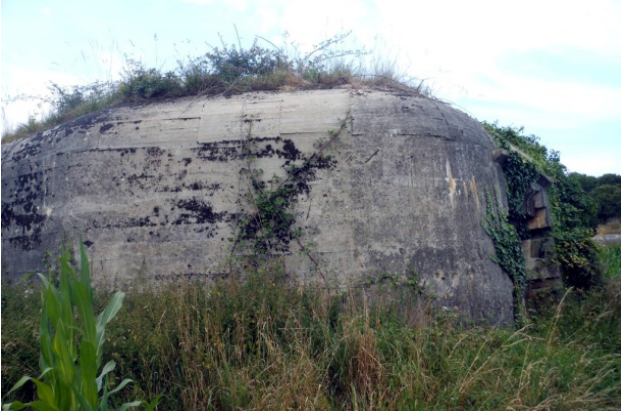

(a)

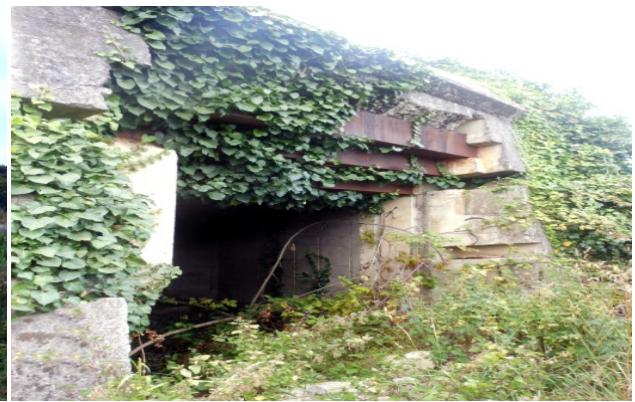

(b)

Figure 6. Kullak battery: (a) R669 (b)—front side; (b) R669 (b)—front side aperture of the fire room with splinter guards partially covered by the vegetation. 


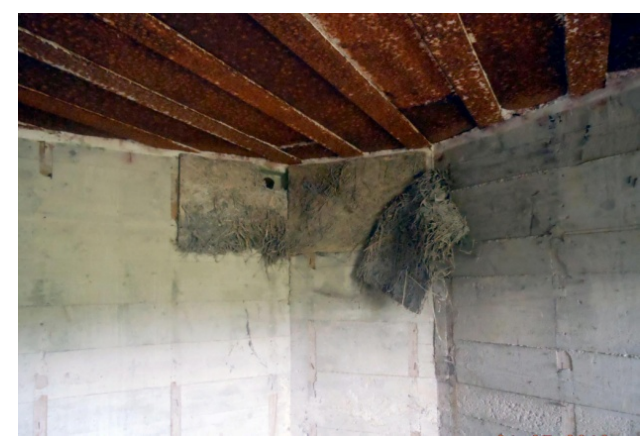

(a)

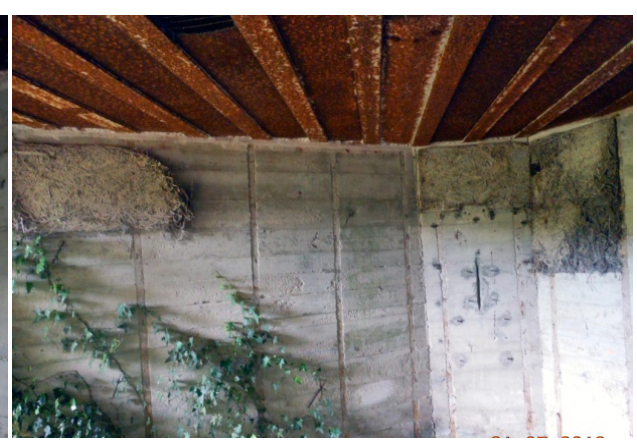

(b)

Figure 7. Kullak battery: (a), (b) R669 (b) interior of the fire room with panels of the thermal and/or acoustic insulation system on the walls.

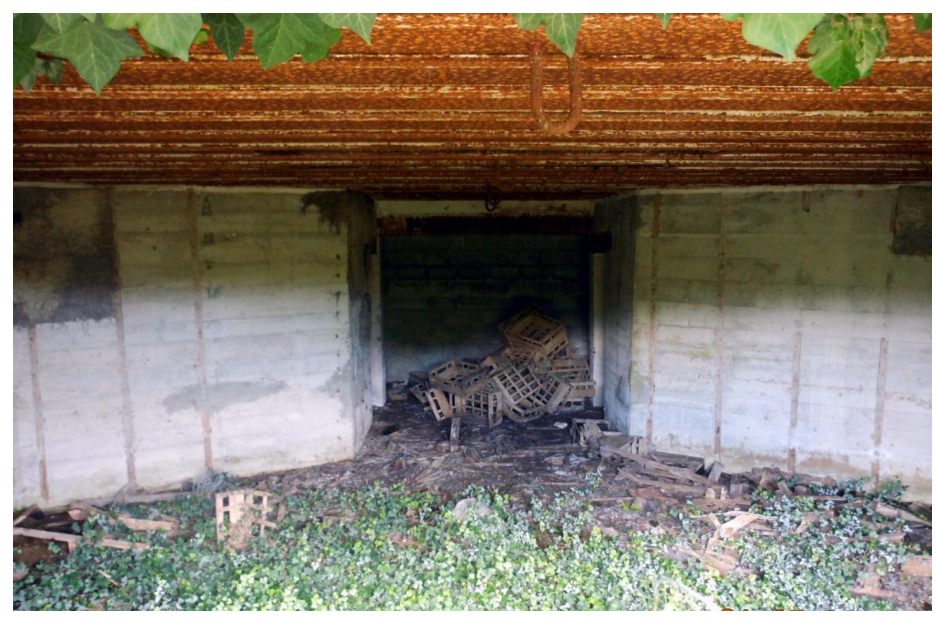

Figure 8. Kullak battery: R669 (b) fire room-at the centre walled rear side aperture, on the left entrance of the ammunition room, on the right entrance of the combat gas extraction system room, on the metal ceiling two joints for the gun lifting, on the left and right walls panels of the thermal or acoustic insulation system.

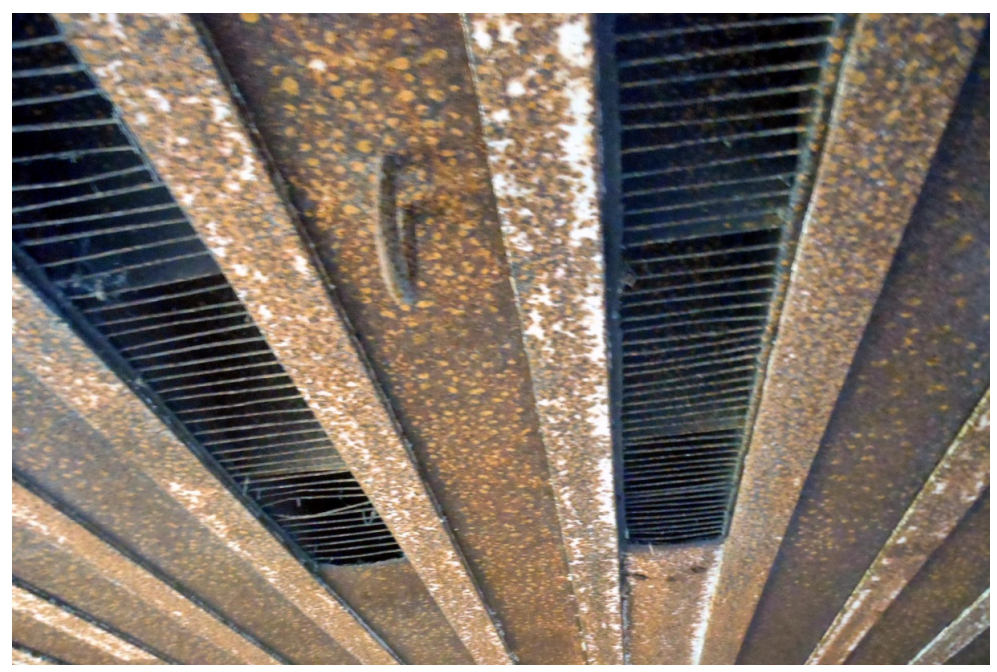

Figure 9. Kullak battery : R669 (b) - fire room ceiling, grids of the combat gas extraction system and one of the two joints for the gun lifting. 


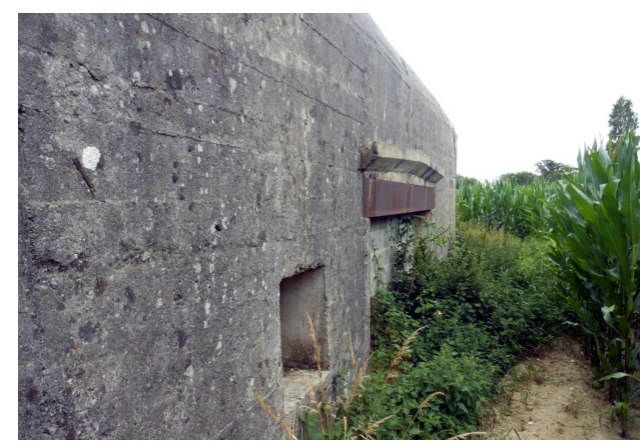

(a)

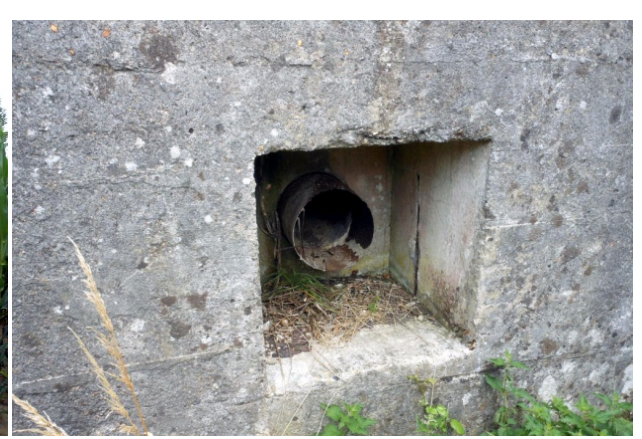

(b)

Figure 10. Kullak battery: (a) R669 (b) —-walled rear side aperture and niche of the exhausted combat gas pipe; (b) R669 (b) —niche of the exhausted combat gas pipe.

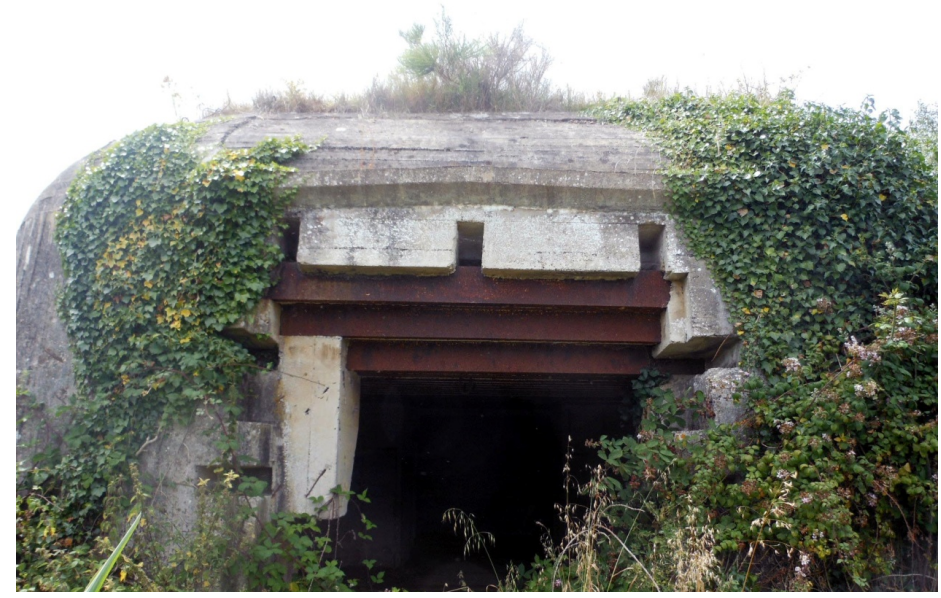

Figure 11. Kullak battery: R669 (c) front side aperture of the fire room with splinter guards partially covered by the vegetation.

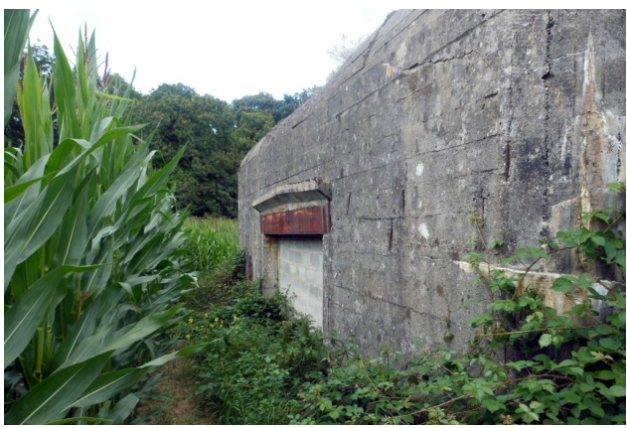

(a)

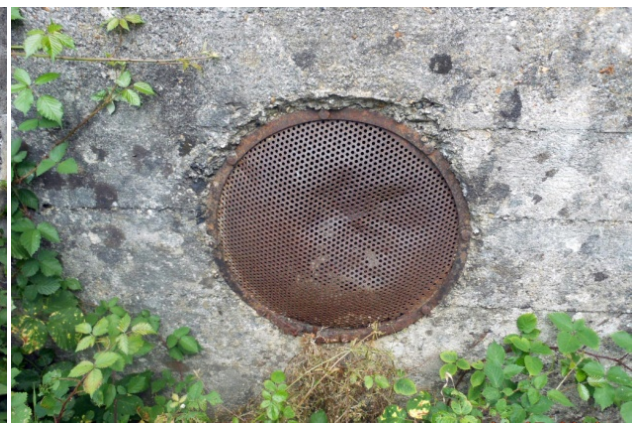

(b)

Figure 12. Kullak battery: (a) R669 (c) —-walled rear side aperture; (b) R669 (c) — grid on the exhausted combat gas pipe.

According to Mr. Peyle (Pottier, 2014), the absence of a fire direction bunker (Figure 2) let to think that the observatory bunker R120a of the Pointe de la Varde support point (Ra109) directed the fire of the Kullak battery as well as the fire of the batteries of La Richardais (II403), Les Ormeaux (II405 - S160a) and La Haize (W601). 


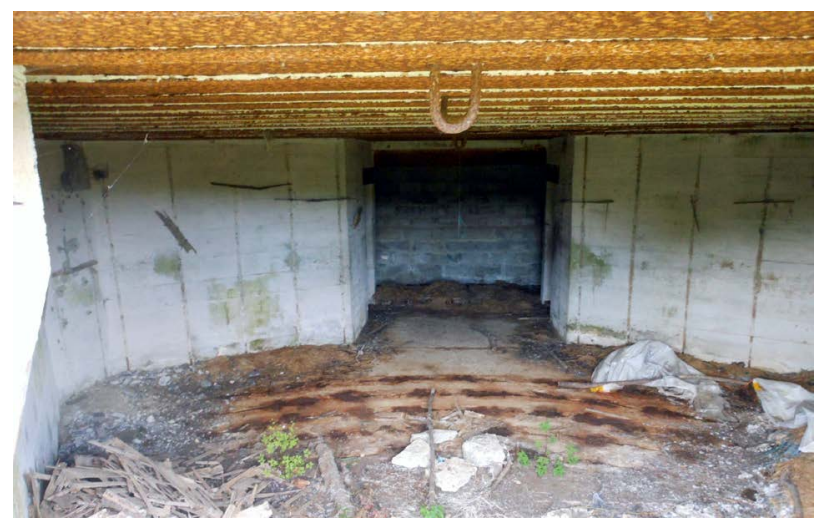

Figure 13. Kullak battery: R669 (c) fire room-at the centre walled rear side aperture, on the left entrance of the ammunition room, on the right entrance of the combat gas extraction system room, on the metal ceiling two joints for the gun lifting, on the floor arcuate rails of the vibration dampening system, on the left and on the right wall rests of the supports for the panels of the thermal and/or acoustic insulation system, on the floor arcuate rails of the vibration dampening system.

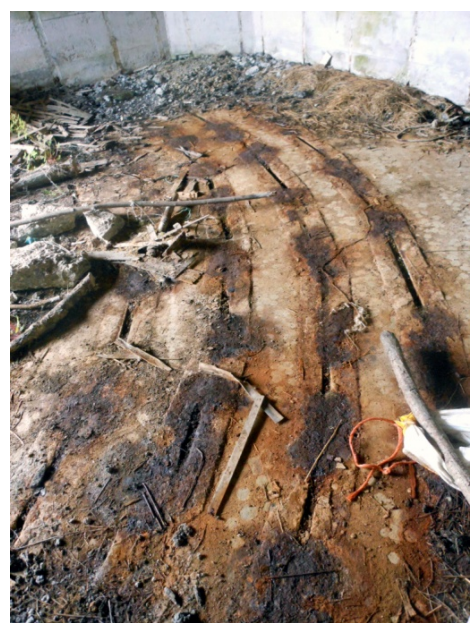

(a)

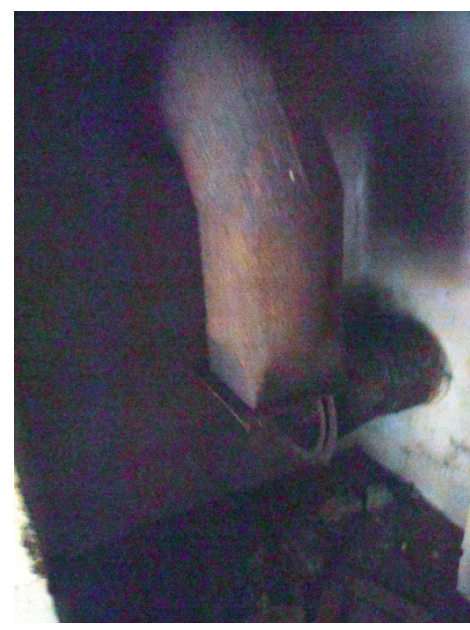

(b)

Figure 14. Kullak battery: (a) R669 (c) -fire room, details of the arcuate rails of the vibration dampening system; (b) R669 (c)_combat gas extraction system room, details of the combat gas extraction tubes, the extraction pump is disappeared, but according to the big volume of gas to be extracted from the fire room and the reduced dimension of the combat gas extraction system room it is possible that the pump was electrically operated.

\section{The Stützpunkt of the Pointe de la Varde}

It was on 1942 (Superforum, 2010) that, for the defence of Saint-Malo, the Organisation Todt proceeded to the improvement of the French fortifications of the Pointe de la Varde $\left(48^{\circ} 40^{\prime} 54.6^{\prime \prime} \mathrm{N}, 1^{\circ} 59^{\prime} 19.9^{\prime \prime} \mathrm{W}\right)$ to create a Stützpunkt (support point) by adding the bunkers R600/SK, R667m, R655, R112a, R502, R506, R622/SK, R611, R611/SK, R621, R653, R120a, Kl.Flw, s.MG 36(t), fourteen Abw.FLw.42(r), a bunker for projector of 30 $\mathrm{cm}$ and two Flak bunkers for $2 \mathrm{~cm}$ gun. In a first period the support point was occupied by a detachment of the Festung Komp. LXXIV formed by four non-commissioned of- 
ficers and forty-eight soldiers under the command of the Major Liebreich. On 8th August 1944 the support point, reinforced by three heavily armed barges anchored near the Pointe open the fire against advancing American troops. Spotted by the Americans the barges returned in the port of Saint-Malo. On 11th August despite a strong artillery pre- paration, a first attack of the American Infantry ended without success. On 12th August the support point was still in connection with the near support points W109a and W600. But, after an intense fire of fifty machine guns on the entrance of the bunkers, the network of trenches and machine gun nests system that closed the access to the Pointe collapsed. At 20:00 only two machine guns were still ready to combat. At 22:30 two American companies invested the support point, capturing four officers and hundred-six German soldiers.

The visit of the support point of the Pointe de la Varde (AOK 7, KVA A1, KvGr Rance, KvUGr Festung Saint Malo, RA 109) (Figure 15) took place on 18th August 2010 and permitted to identify many of the above mentioned bunkers and in particular the observatory bunker R120a (Figures 16-20) mentioned by Mr. Peyle (Pottier, 2014).

The bunker R120a presented a well preserved concrete structure, here and there covered by graffiti without visible damages due to said combats. All the original internal furniture disappeared. In particular, it preserves the metallic internal structure of the observatory bell (Figure 19).

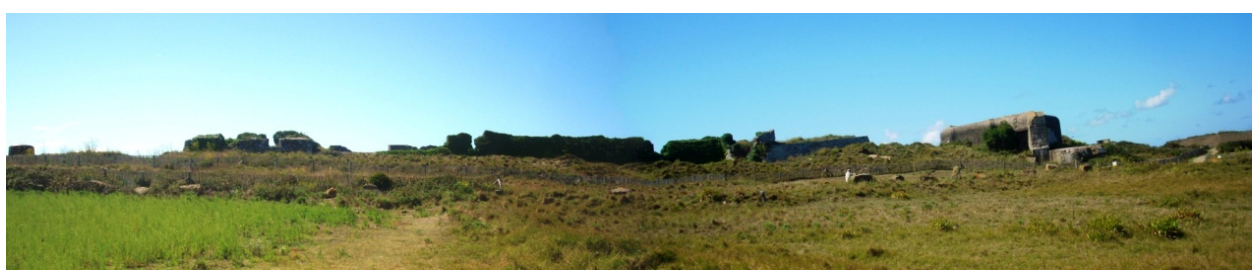

Figure 15. Pointe de la Varde support point-overview.

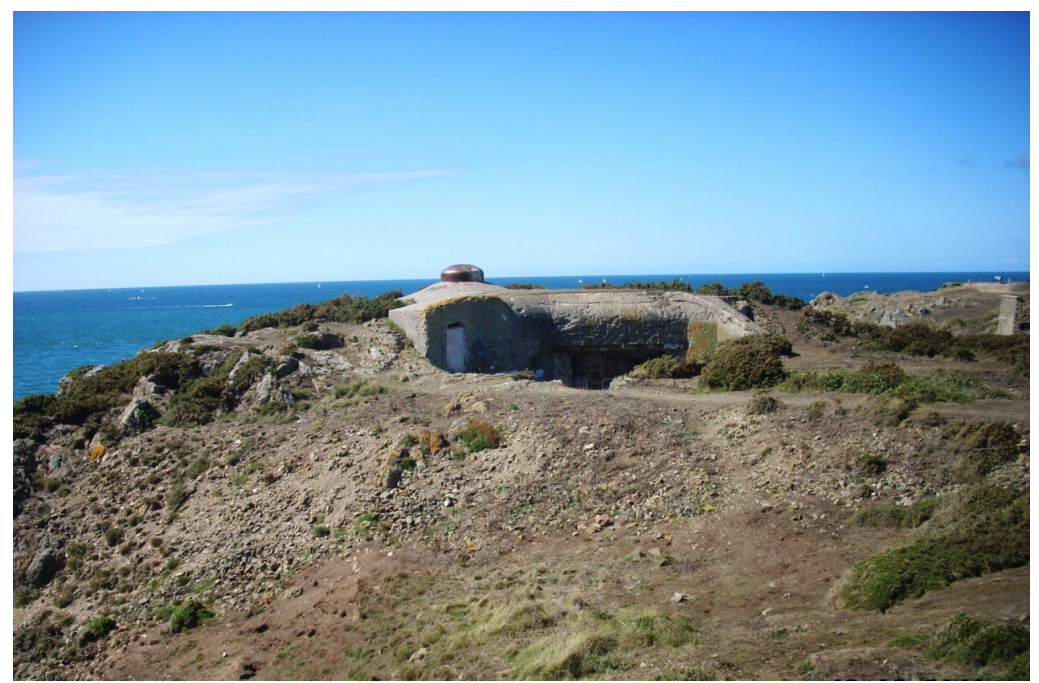

Figure 16. Pointe de la Varde support point: R120a observatory bunker $\left(48^{\circ} 40^{\prime} 53.4^{\prime \prime} \mathrm{N}, 1^{\circ} 59^{\prime}\right.$ $23.4 " \mathrm{~W}$ ) —on the left, white painted, entrance of the uncovered lookout post and the observatory bell, in the middle bunker entrance and close combat room, on the right protective wing. 


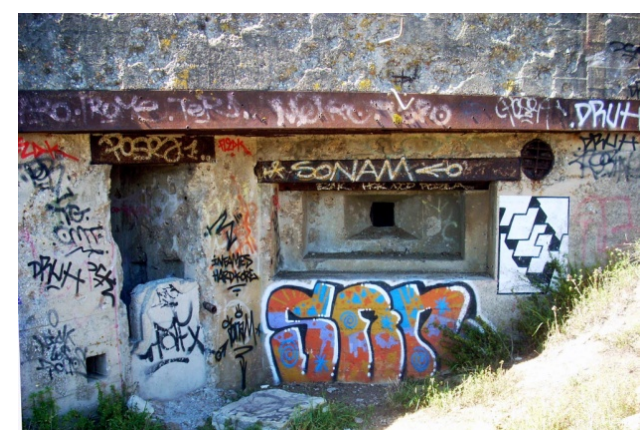

(a)

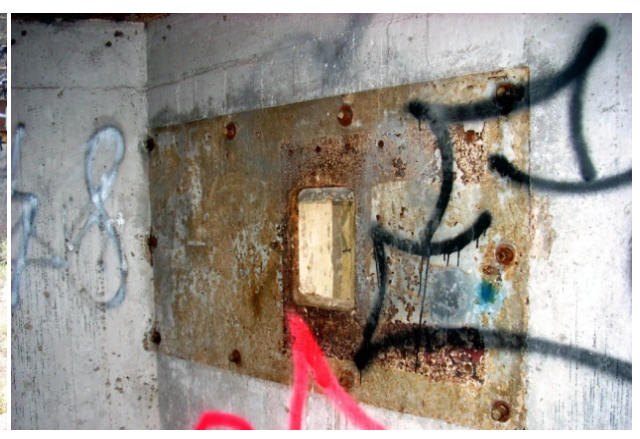

(b)

Figure 17. Pointe de la Varde support point: (a) R120a-entrance and external details of the close combat room fire louver; (b) R120a-details of the interior of the bunker close combat room.

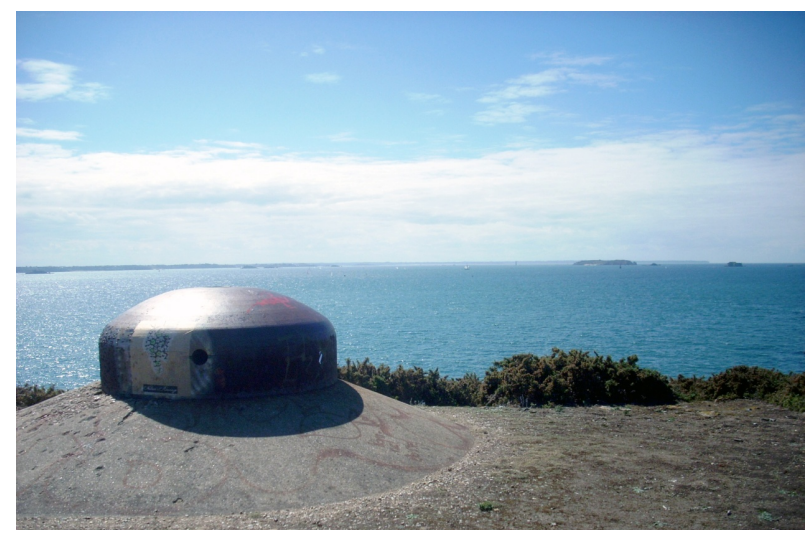

Figure 18. Pointe de la Varde support point: R120a observatory bunker-on the left bunker observatory bell, on the left, at the horizon, just barely visible, the Cap Frehel, and on the right the Cezambre island.

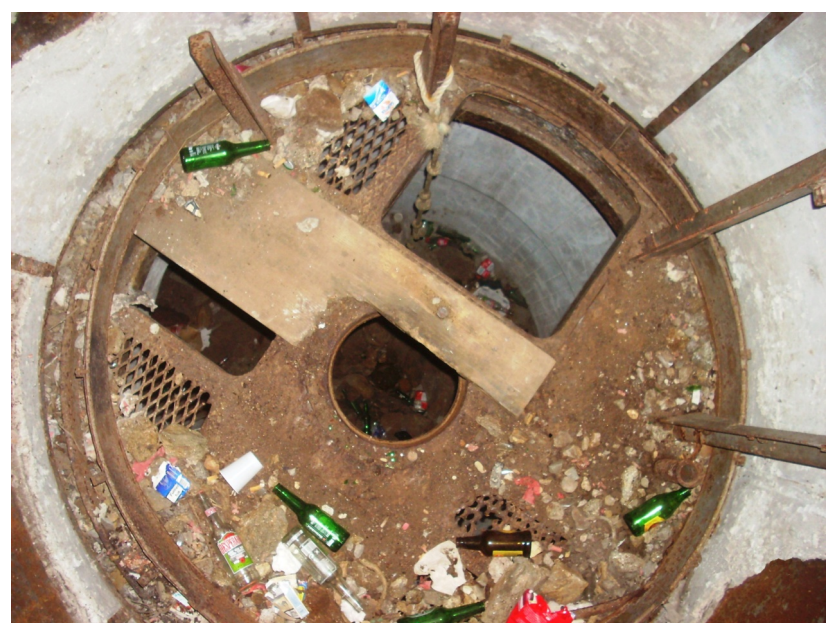

Figure 19. Pointe de la Varde support point: R120a observatory bunker-interior of the observatory bell.

\section{The Ville Besnard Logistic Base}

An apparently lonely bunker $\left(48^{\circ} 39^{\prime} 47.4^{\prime \prime} \mathrm{N}, 1^{\circ} 57^{\prime} 55.5^{\prime \prime} \mathrm{W}\right)$ gets up at the locality called 
Ville Besnard. It indicates the place of the Ville Besnard logistic base (AOK7, KVA A1, KvGr Rance, KvUGr Festung Saint Malo, RA 603) designated mainly for the storage and supply of water to the Festung and nowadays to the Paramé district of Saint-Malo (Figure 21).

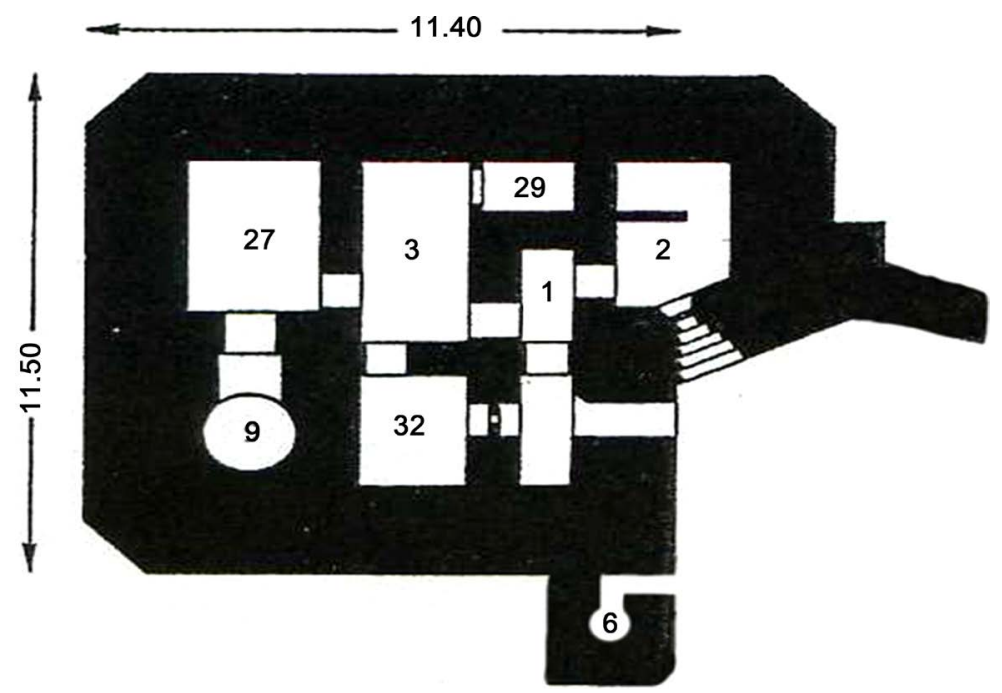

Figure 20. Pointe de la Varde support point: R120a observatory bunker: 1. gas lock, 2. close combat room, 3. troop room, 6. uncovered lookout post, 9. observatory bell, 27. computing room, 29. supply depot, 32. commandment room.

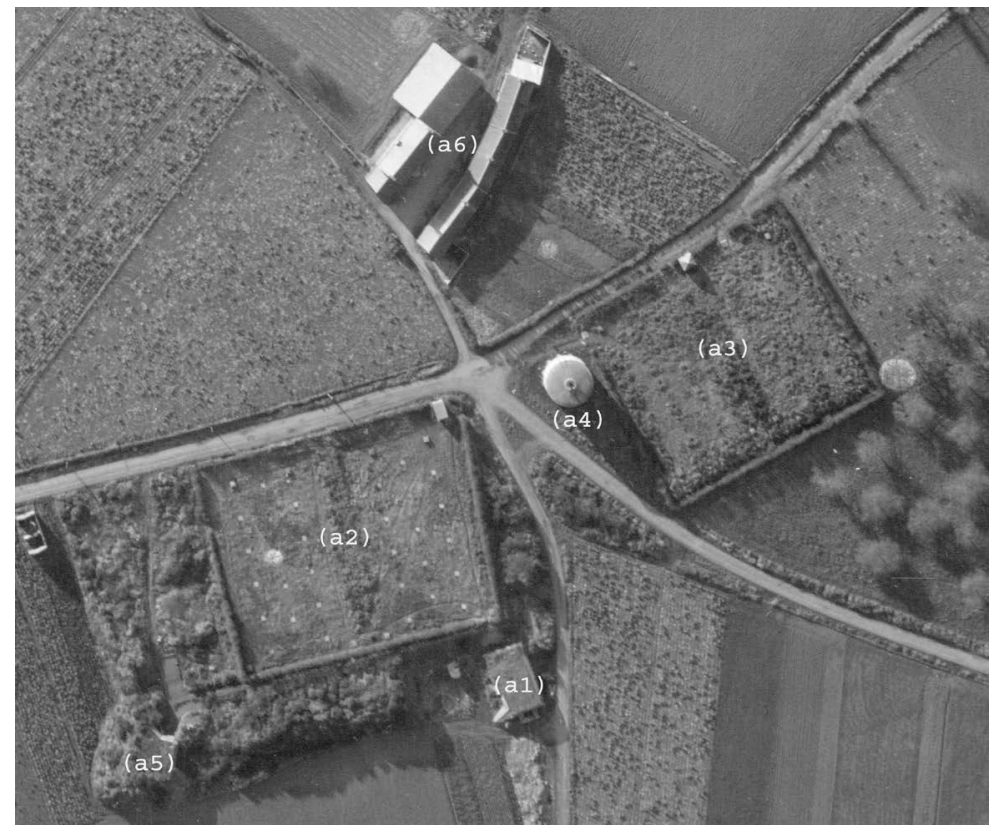

Figure 21. Ville Besnard logistic base on 1948-(a1) lonely bunker, modified version of R625 or R640 bunker, (a2) area with two water cisterns of German construction and surveillance post near the entrance on the road, (a3) area with two water cisterns of German construction and surveillance post on the road (a4) water tower, (a5) R630 bunker now on the site of a transmission center of Antenne Orange, (a6) farm

IGNF_PVA_1-0_1948-04-16_C3639-0511_1948_MISSIONBRETAGNE108_0095. 
The visit of the Ville Besnard base took place on 19th August 2011. The lonely bunker (Figures 22-25) appears to be a modified version of R625 or R640 bunker for a 3.7 $\mathrm{cm}$ Pak 36 or $4.2 \mathrm{~cm} \mathrm{Pak} 41$ anti-tank gun, without uncovered lookout post and close combat room, but provided with a protection wing on a side of one of the rear aperture of the fire room. It presented a well preserved concrete structure without visible damages due to bombardments and/or combats. The entrance for the personnel and the fire room were filled by debris and did not allow the visit of the bunker interior. Therefore, the plane of the bunker (Figure 18) is rather hypothetical. The enclosures covered by thorny vegetation did not allow to access and inspect the water cisterns areas (a2, a3). A bunker R630 for a machine gun and six soldiers on the site of a Antenne Orange transmission centre of Saint-Malo was not accessible.

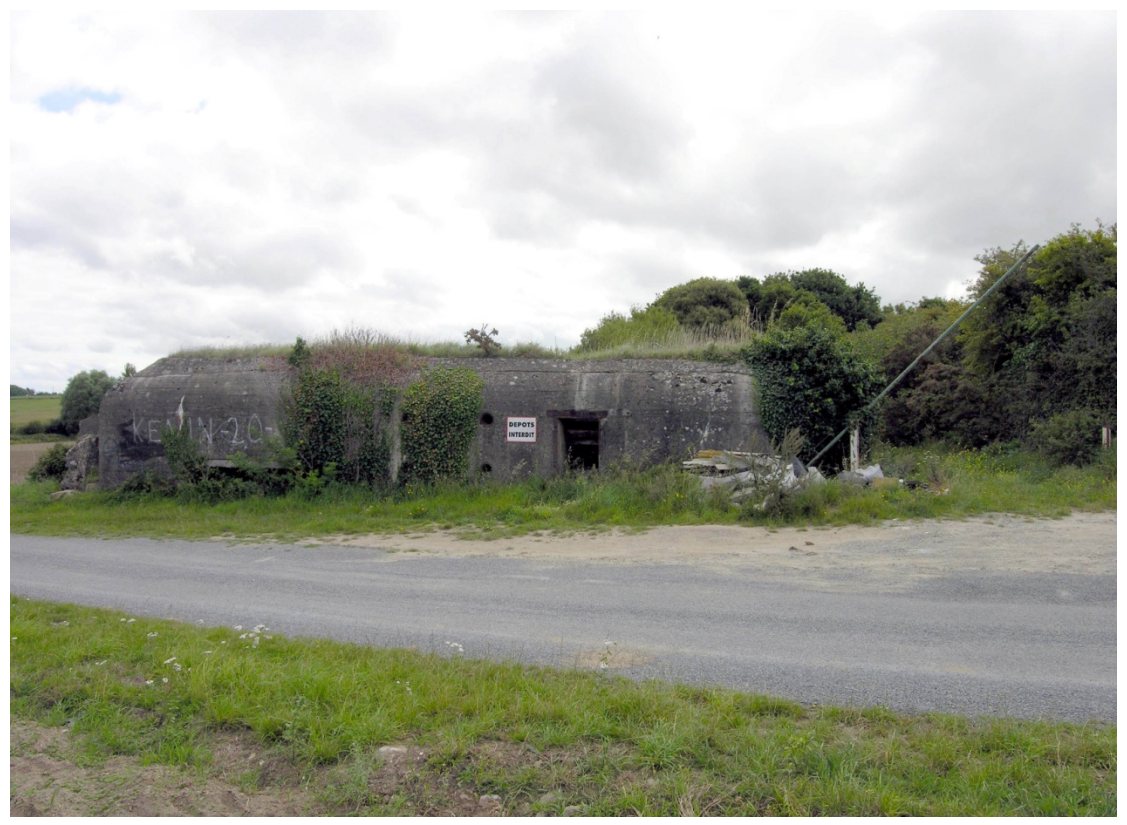

Figure 22. Ville Besnard logistic base: lonely bunker-on the left front aperture of the fire room, at the road level, on the centre four air vents, on the right personnel entrance, behind the bunker, cistern area (a2).

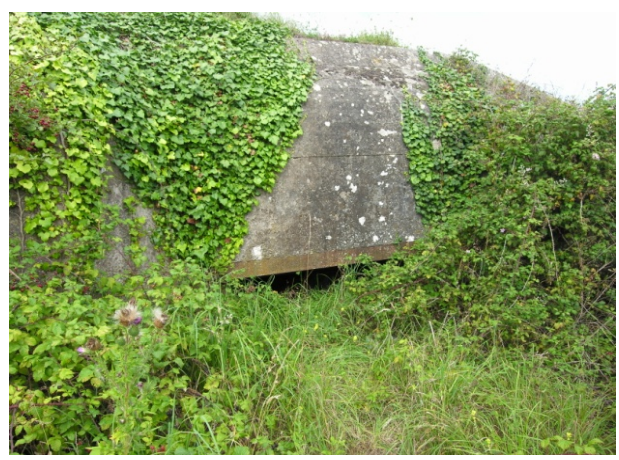

(a)

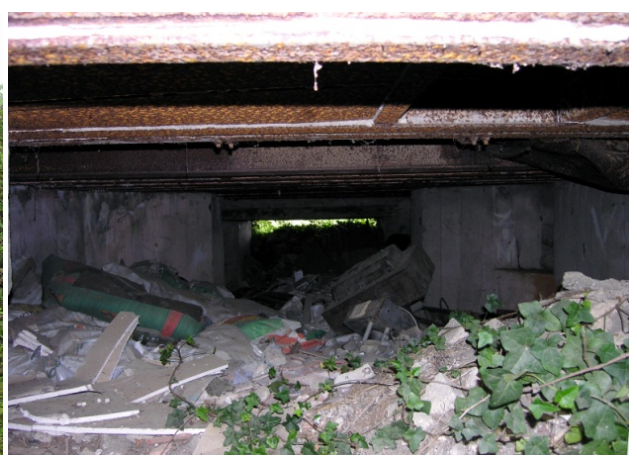

(b)

Figure 23. Ville Besnard logistic base: (a) lonely bunker-rear side aperture of the fire room; (b) lonely bunker-interior of the fire room filled with debris. 


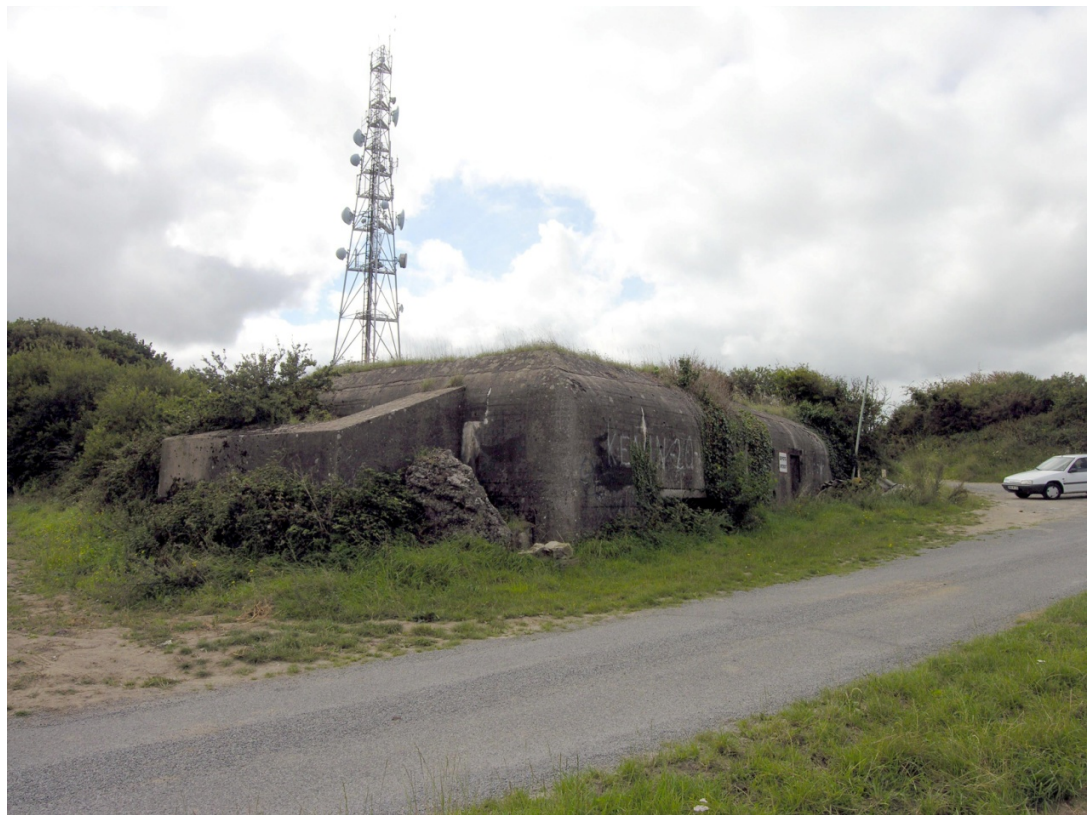

Figure 24. Ville Besnard logistic base: lonely bunker-on the left exhausted shell cases pit and Antenne Orange mast.

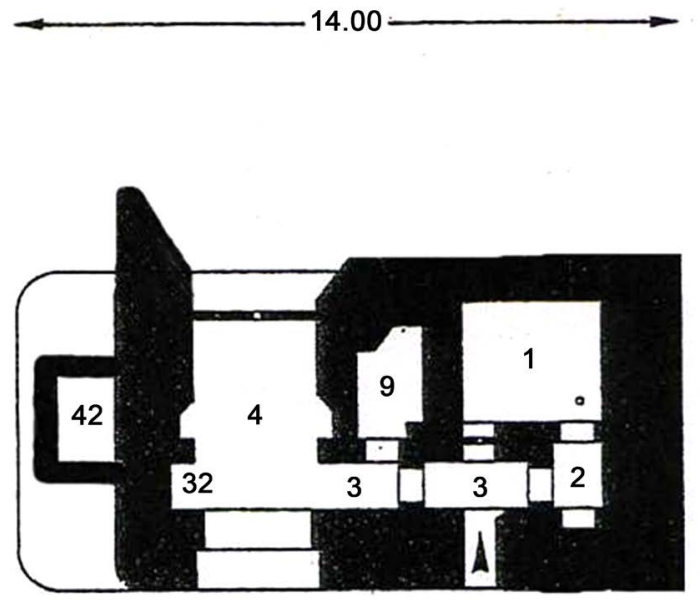

(1)
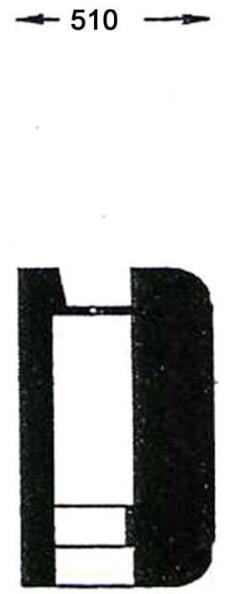

(2)

Figure 25. Ville Besnard logistic base: lonely bunker: (a) hypothetical plane of the bunker-1. troop room, 2. gas lock, 3. internal corridor, 4. fire room, 9. ammunition room, 32. ventilation recesses, 42. exhausted shell cases pit; (b) side plane.

\section{The Bastion de Saint Ideuc Base}

About 2 kilometres north from the Ville Besnard logistic base was the Bastion de Saint Ideuc base $\left(48^{\circ} 39^{\prime} 35.0^{\prime \prime} \mathrm{N}, 1^{\circ} 57^{\prime} 57.0^{\prime \prime} \mathrm{W}\right.$ ) (Figure 26) which now is on a private terrain and not accessible to the public.

\section{Les Ormeaux Artillery Battery}

The visit of Les Ormeaux artillery battery (AOK7, KVA A1, KvUGR Festung Saint- 
Malo, Batt. 405, Ra 160a) (48 $\left.38^{\prime} 47.2^{\prime \prime} \mathrm{N}, 1^{\circ} 58^{\prime} 47.5^{\prime \prime} \mathrm{W}\right)$, took place on 19th August 2011. The battery comprised four R669 bunkers for $150 \mathrm{~mm}$ guns as the Kullak battery. The area of the base is now occupied by the cemetery of Les Ormeaux of Saint-Malo. One R669 bunker (Figures 27-30) is used by the cemetery services as materials and vehicles depot. Although covered by the vegetation it presented a well preserved concrete structure without evident damages due to bombardments and/or combats (Figure 29 \& Figure 30). The original internal furniture disappeared. Surprisingly, the cemetery personnel considered the small ammunition and combat gas extraction system rooms of the bunker as troop rooms and the German soldiers so small to live in them. A second R669 bunker (Figure 31 \& Figure 32) is located just outside of the cemetery area but still used by the cemetery services as materials and vehicles depot. It presented a well preserved concrete structure without evident damages due to bombardments and/or combats. The apertures of the fire room were closed and the insufficiently illumination prevented the inspection of the interior. Two other R669 are included in the cemetery area. A bunker R660, shelter for battery chargers, used by the cemetery services, now covered by the vegetation and inaccessible, is located not far near a road at the exterior of the cemetery area.

\section{The Hôpital des Rosais Base}

The Hôpital dest Rosais base (AOK7, KVA A1, KvGr Rance, KvUGr Festung Saint

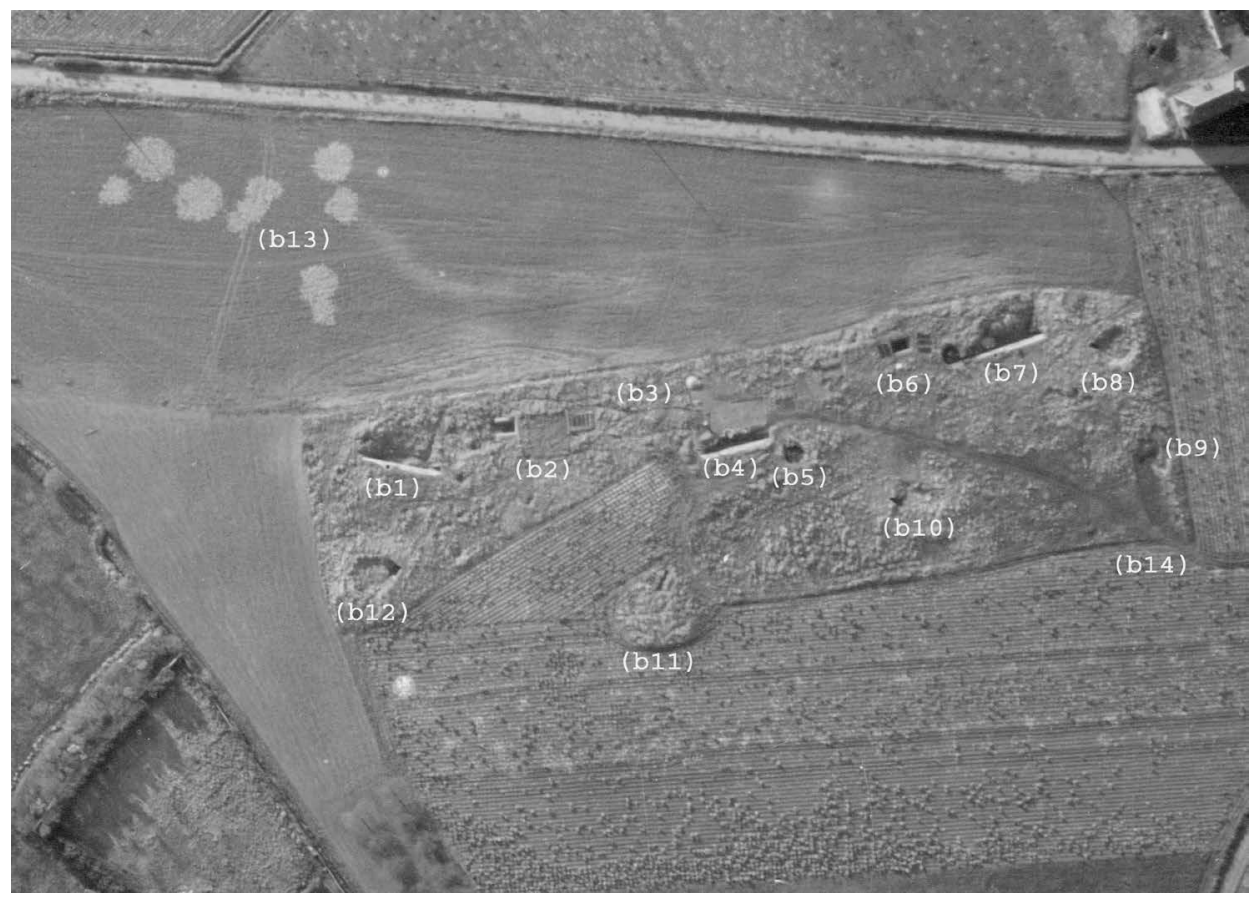

Figure 26. Bastion Saint Ideuc on 1948-b1., b4., b7., b11. personnel shelter bunker, b2., b6. ammunition bunkers, b3. trench between the bunkers b1., b2. and b4., b5., b8 possible emplacements for $20 \mathrm{~mm}$ gun; b9., b10., b12 emplacements for anti-aircraft Vicker-Armstrong 75 $\mathrm{mm}$ gun, b13. image defects or possible filled bombing craters, b14. bastion access road (Pottier, 2014) IGNF_PVA_1-0_1948-04-16_C3639-0511_1948_MISSIONBRETAGNE108_0095. 


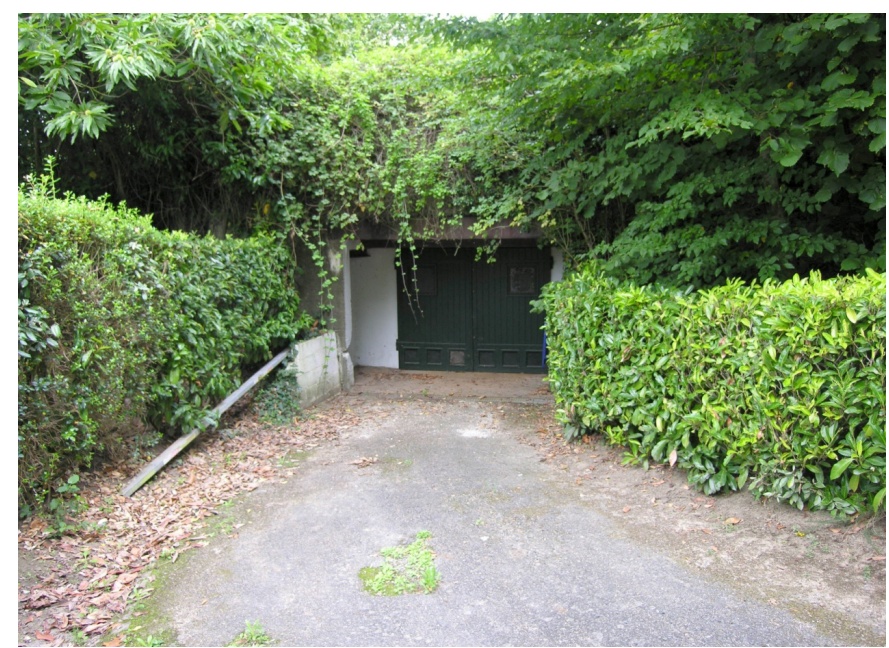

Figure 27. Les Ormeaux battery: R669, front aperture of the fire room, the green wooden door is not of origin.

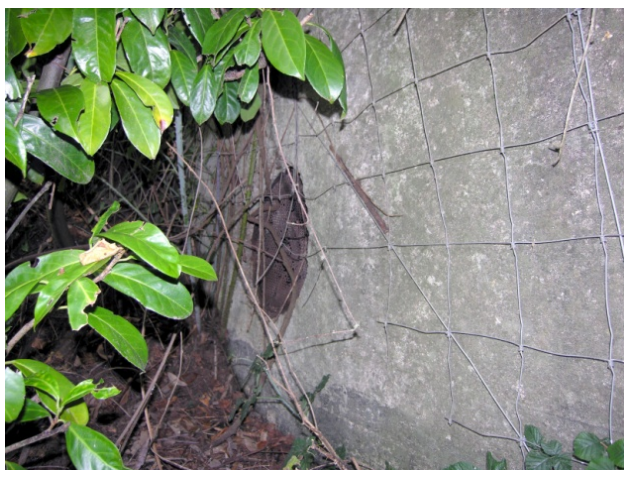

(a)

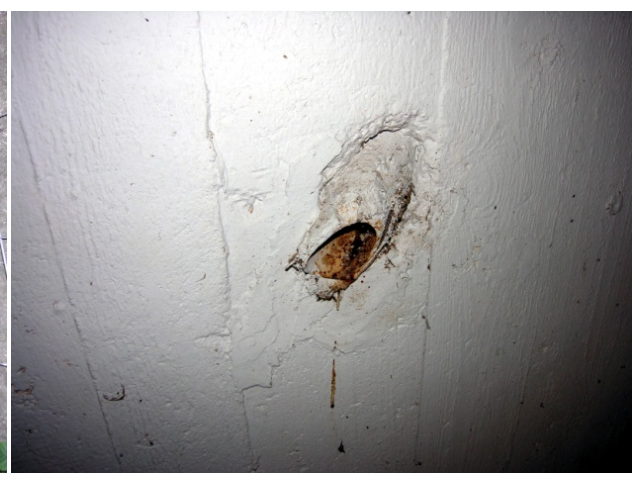

(b)

Figure 28. Les Ormeaux battery: (a) R669-air vents on the front facade ; (b) R669—cable passage on the front facade.

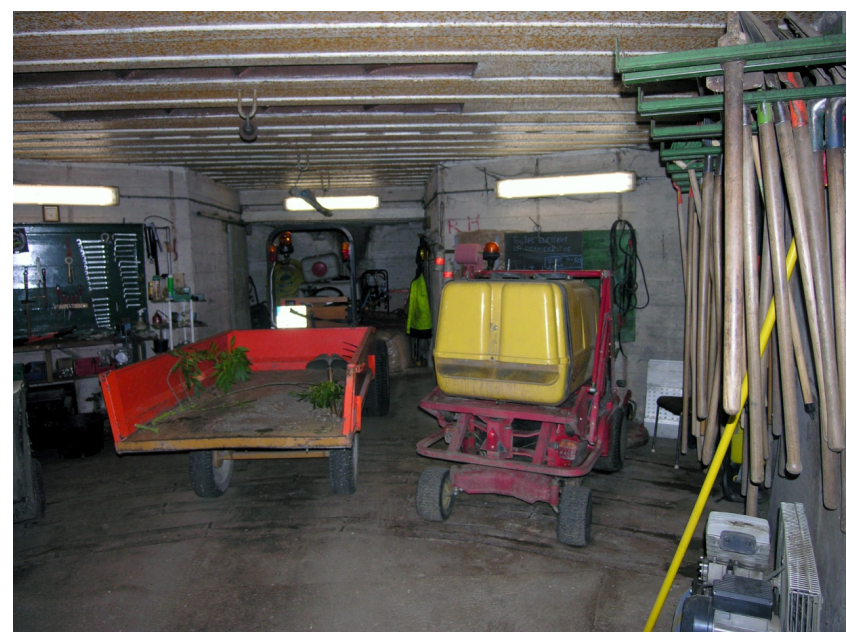

Figure 29. R669 fire room-at the centre walled rear side aperture, on the metal ceiling three joints for the gun lifting and grids of the combat gas extraction system, on the floor the arcuate rails of the vibration dampening system. 


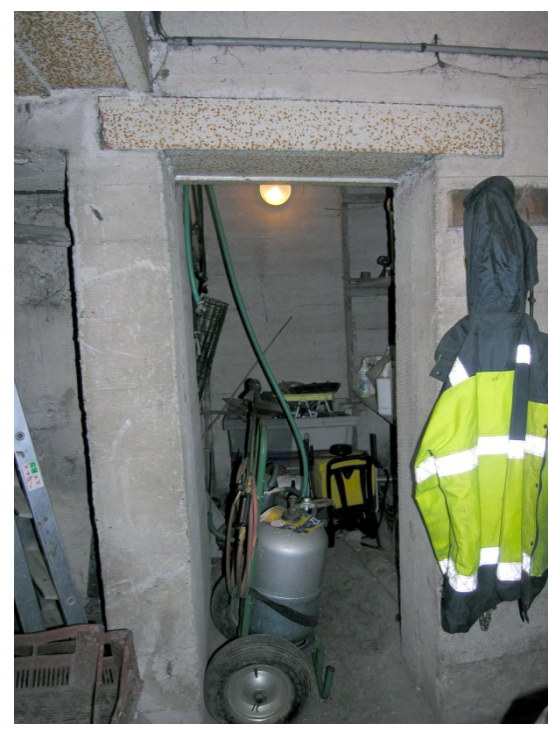

(a)

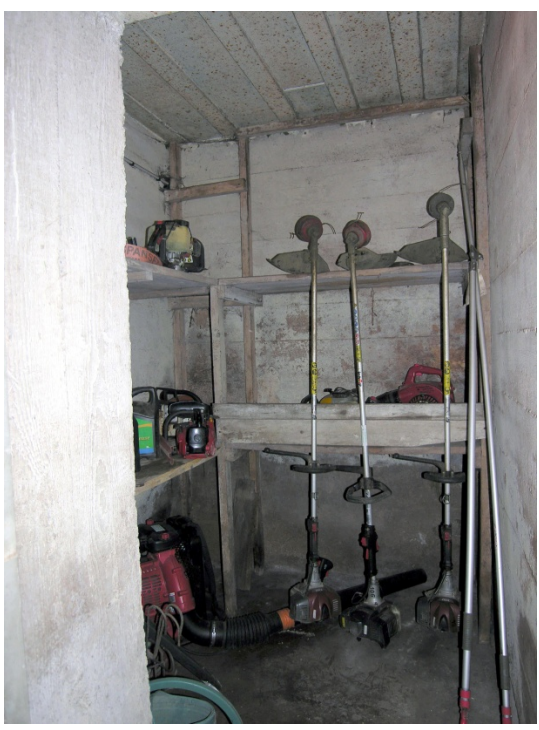

(b)

Figure 30. Les Ormeaux battery: (a) R669-ammunition room; (b) R669-ammunition room or combat gas extraction system room, no rests of the gas extraction system remained.

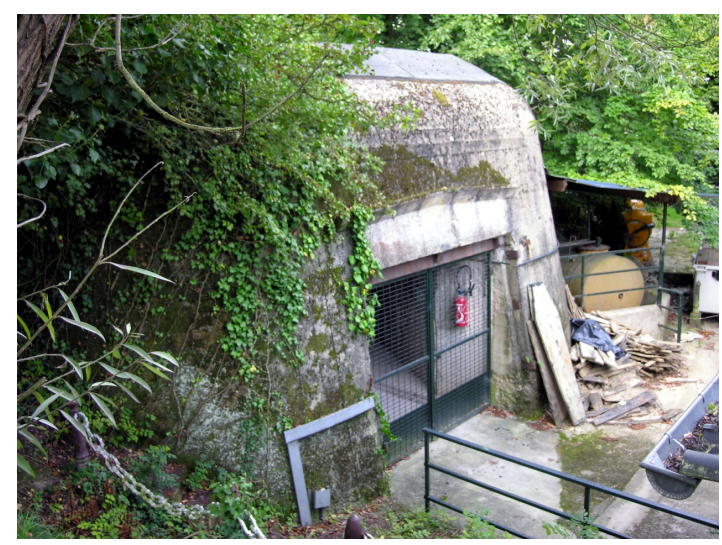

Figure 31. Les Ormeaux battery: R669 bunker-details of the facade, the metallic door is not of origin.

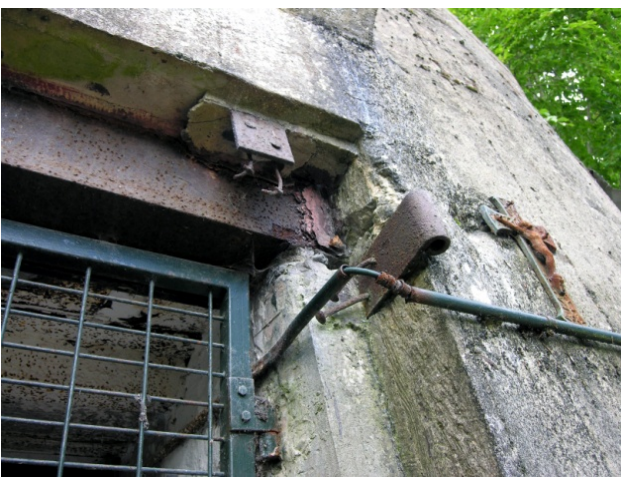

(a)

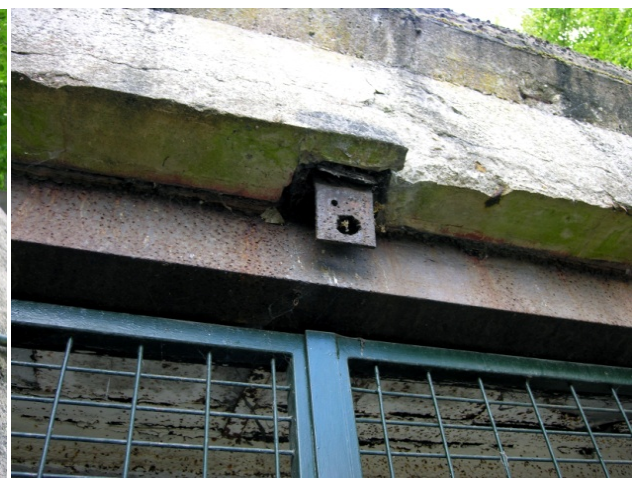

(b)

Figure 32. Les Ormeaux battery: (a), (b) R669—-details of the original doorposts of the fire room front aperture. 
Malo, Les Rosais, Ra281a) consisted mainly of a R118 b bunker opposed to the old building of the hospital (Figure 33). The location of the two floors, first aid R118 bunker $\left(48^{\circ} 37^{\prime} 32.8^{\prime \prime} \mathrm{N}, 2^{\circ} 00^{\prime} 39.9^{\prime \prime} \mathrm{W}\right)$ (Figures 34-37) was not chosen at random, in fact, it was close to the requisitioned, old building of the hospital. The bunker was built for enhancing the first aid to the German soldiers provided in the old building. It comprised a treatment room and two rest rooms. Its $2 \mathrm{~m}$ thick walls allowed the military surgeons to operate safely during the battle of Saint-Malo. At the moment of our visit on 5th September 2011, the bunker presented a well preserved concrete structure without damages due to bombardments and/or combats. The interior was not accessible. In the year 2012 the construction of an extension of the hospital involved the demolition of the bunker part sheltering the water tank room, the provisions room and one of the rest rooms (Figure 34).

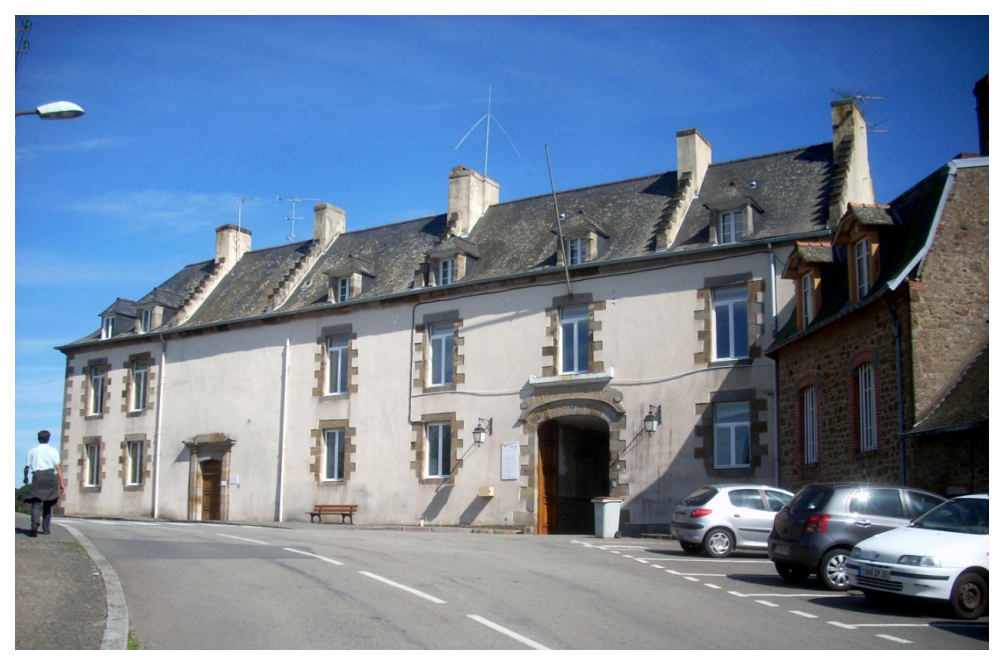

Figure 33. Hôpital des Rosais base-requisitioned, old building of the hospital.

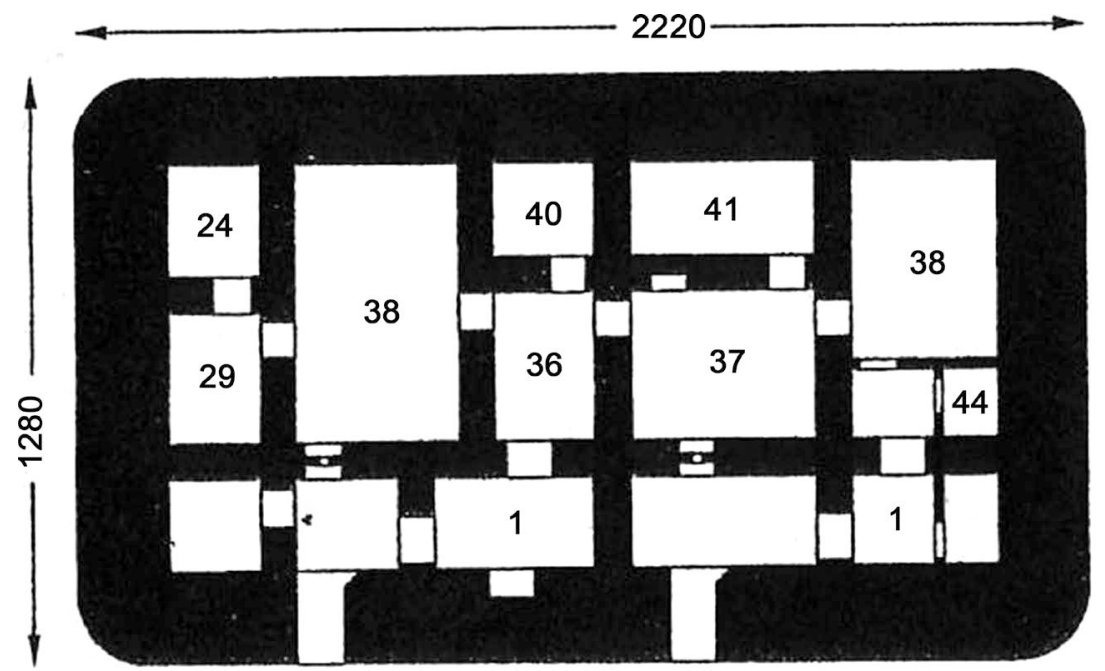

Figure 34. Hôpital des Rosais base - first aid R118 bunker (Rolf, 1998)-1. gas lock, 38. rest room, 24. water tank room, 40. officers room, 29. provisions room, 41. nurse room, 36. admission room, 44. douches, (37) treatment room. 


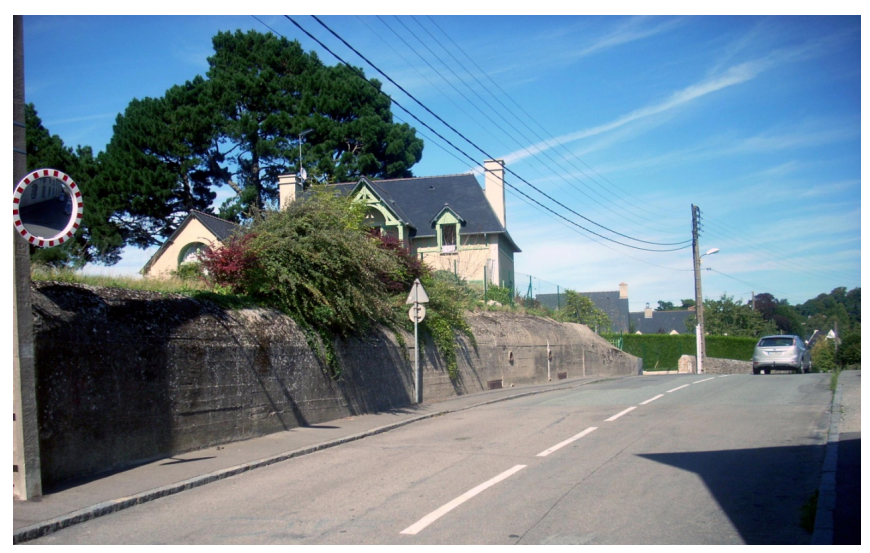

Figure 35. Hôpital des Rosais base-first aid bunker R118 opposed to the old building of the hospital, on the left the part of the bunker demolished in the year 2012, in the middle the air vents and the entrances of the bunker at the road level, on the right the protection wing.

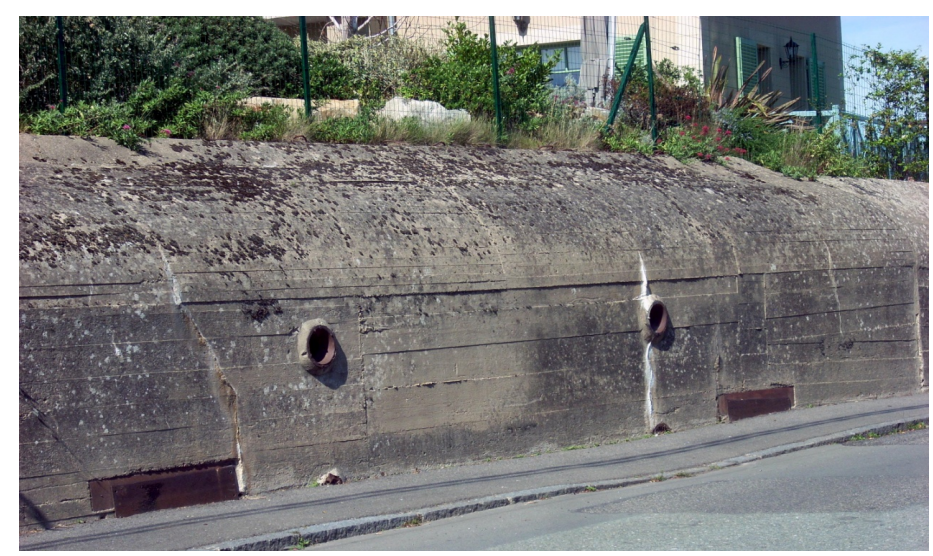

Figure 36. Hôpital des Rosais base-first aid R118 bunker, entrances at the road level and air vents.

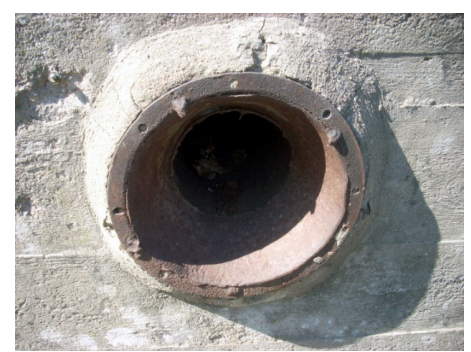

(a)

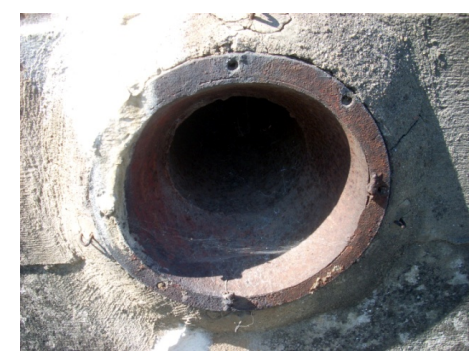

(b)

Figure 37. Hôpital des Rosais base-first aid R118 bunker, air vents of the bunker without protection grid.

\section{Conclusion}

We are satisfied with our visits to the above German military structures. Many of them remain visible and accessible and witness the confidence of the Germans in static military offensive and defensive structures. The Kullak artillery battery, the Pointe de la Varde support point, the Bastion de Saint Ideuc base, the Hôpital des Rosais base have 
lost their military value and because of their obsolescence with respect to the modern military doctrines based on a rapid first strike and precision bombing, they will never recover a military one. Their bunkers remain silent witnesses of a recent tragic period in the life of Saint-Malo. On the contrary, the bunkers of the Les Ormeaux artillery battery and the cisterns of the Ville Besnard logistic base are well integrated in the urban context and support the actual exigencies of Saint-Malo.

\section{References}

Corlouer, D., \& Rose, Y. (1965). Lorsque le béton remplaça la pierre. La Varde-Aleth-Cezembre, Saint-Malo.

Dupont, A., \& Peyle, E. (1994). Le Mur de l'Atlantique sur la Côte d'Emeraude. Ed. Danclau, $1^{\mathrm{er}}$ Trimestre 1994, ISBN 2907019201, 9782907019200.

Pottier, L. (2014). Compte rendu de l'entretien avec Mr Eric Peyle. le 13 juin 2014.

Superforum (2010).

http://atlantikwallbretagne.superforum.fr/36-festung-st-malo-ra-s-109-pointe-de-la-varde

Rolf, R. (1998). Typologie du Mur de l'Atlantique. Beetsterwaag, ISBN 906476045 3, NUGI 923.

Submit or recommend next manuscript to SCIRP and we will provide best service for you:

Accepting pre-submission inquiries through Email, Facebook, LinkedIn, Twitter, etc.

A wide selection of journals (inclusive of 9 subjects, more than 200 journals)

Providing 24-hour high-quality service

User-friendly online submission system

Fair and swift peer-review system

Efficient typesetting and proofreading procedure

Display of the result of downloads and visits, as well as the number of cited articles

Maximum dissemination of your research work

Submit your manuscript at: http://papersubmission.scirp.org/ 